
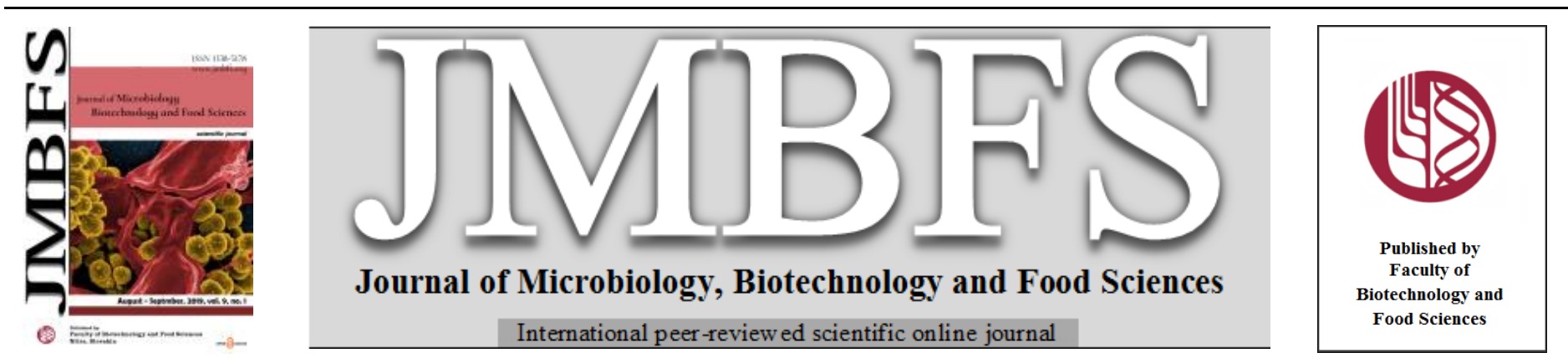

\title{
THE EFFECT OF BEE PRODUCTS AND PROBIOTIC ON MEAT PERFORMANCE OF BROILER CHICKENS
}

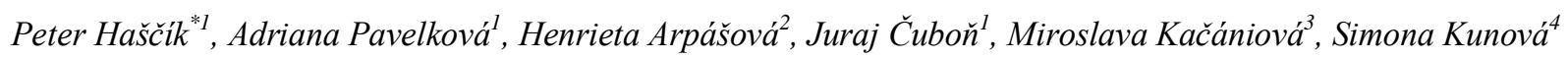

\author{
$\operatorname{Address}(e s)$ : \\ ${ }^{1}$ Slovak University of Agriculture in Nitra, Faculty of Biotechnology and Food Sciences, Department of Animal Products Evaluation and Processing, Tr. A. Hlinku 2, \\ 94976 Nitra, Slovakia. \\ ${ }^{2}$ Slovak University of Agriculture in Nitra, Faculty of Agrobiology and Food Resources, Department of Poultry and Small Farm Animals, Tr. A. Hlinku 2, 94976 \\ Nitra, Slovakia. \\ ${ }^{3}$ Slovak University of Agriculture in Nitra, Faculty of Biotechnology and Food Sciences, Department of Microbiology, Tr. A. Hlinku 2, 94976 Nitra, Slovakia. \\ ${ }^{4}$ Slovak University of Agriculture in Nitra, Faculty of Biotechnology and Food Sciences, Department of Food Hygiene and Safety, Tr. A. Hlinku 2, 94976 Nitra, \\ Slovakia.
}

*Corresponding author: peter.hascik@uniag.sk

doi: 10.15414/jmbfs.2019.9.1.88-92

\section{ARTICLE INFO}

Received 17. 1. 2019

Revised 19.3. 2019

Accepted 19.3.2019

Published 1. 8. 2019

Regular article OPEN $\partial_{\text {ACCESS }}$

\begin{abstract}
The aim was the evaluation of meat performance in chickens Ross 308 after the addition of bee pollen and propolis in a combination with probiotic into diet for broiler chicken. A total of 180 Ross 308 broiler chickens of male and female sex were randomly divided into 3 groups $(\mathrm{n}=60)$ : the control group (C) without additional supplementation, experimental group E1 supplemented with $400 \mathrm{mg}$ bee pollen extract per $1 \mathrm{~kg}$ of feed mixture and $3.3 \mathrm{~g}$ probiotic (Lactobacillus fermentum) added to drinking water on a daily basis, and experimental group E2 supplemented with $400 \mathrm{mg}$ propolis extract/1 $\mathrm{kg}$ feed mixture and $3.3 \mathrm{~g}$ probiotic (L. fermentum) added to drinking water on a daily basis. The feed mixtures were produced without any antibiotics and coccidiostatics. The fattening period lasted for 42 days. The findings of the work on the meat performance and carcass characteristics of chickens revealed that bee pollen in combination with probiotic was the most suitable feed supplement. Among the most noteworthy parameters affected positively $(\mathrm{P} \leq 0.05)$ by this supplement in comparison with control may be mentioned the breast part weight. Moreover, it seems likely that there was synergistic effect of bee pollen and probiotic manifested by higher live body and carcass weight $(\mathrm{P} \leq 0.05)$ in comparison with the control. Present results would also seem to suggest that propolis supplementation with probiotic had effects on meat performance and carcass characteristics of Ross 308 broiler chicken.
\end{abstract}

Keywords: chicken meat, bee pollen, propolis, probiotic, meat performance

\section{INTRODUCTION}

Chickens are the most popular amongst different poultry species worldwide and globally, there is increasing demand for poultry products. This may be attributed to the alleged healthiness of chicken, higher profit margins over a short period, and high acceptability of poultry products in many culinary traditions (Rama Rao et al., 2006; Sola-Ojo et al., 2013; Haščík et al., 2016). Poultry meat is an important source of nutrients for consumers worldwide. Generally speaking, consumers have become to focused on healthy food with a good taste and relevance to nutritional physiology. Furthermore, they have become concerned of potentially harmful additives such as drug residues, allergenic components, intoxicants, and microbial contamination, which may contribute to global health issues (Grashorn, 2007). Nutritional composition of poultry meat is a result of birds' diet, particularly in the early stages of their life. Knowing the nutritional composition plays a key role in deciding whether the poultry meat can be part of a healthy dietary pattern (Probst, 2009).

Sub-therapeutic doses of antibiotics are widely used in animal feeds as growth promoters to increase performance and animal production, to improve animal health, as well as to effectively regulate pathogens. Nevertheless, due to possible adverse effects of antibiotics, such as bacterial resistance and the presence of antibiotic residues in the final product, the European Commission in 2006 banned the use of antibiotics as growth promoters (Attia et al., 2014; Abou-Zeid et al., 2015). As such, new feed additives of plant origin regarded as natural products acceptable by consumers have been proposed by animal breeders (Kahraman $\boldsymbol{e} t$ al., 2016). In this regard, many researchers have attempted to carry out experiments to study natural feed additives for broilers such as herbs, spices, various plant extracts, antioxidants, enzymes, probiotics and prebiotics as possible antibiotic growth promoter substitutes that could be used in poultry diet in order to reduce possible harmful effects of antibiotics (Khaksefidi and Rahimi, 2005; Khattak et al., 2006; Toghyani et al., 2011; Abdel-Kareem and El-Sheikh, 2015; Abo Omar et al., 2016; Farag and El-Rayes, 2016; Karadas et al., 2016; Ricke, 2018). Recently, propolis and bee pollen have been also considered as possible new feed additives (Kleczek $\boldsymbol{e t}$ al., 2012; Attia et al., 2014; Abou-Zeid et al., 2015; Klarić et al., 2018)

Bee products have been extensively used in traditional folk medicine. There is a new promising insight in the research for bee products, such as propolis, pollen, bee venom, honey, and royal jelly (Seven et al., 2014).

Bee pollen is defined as an agglomerate of pollen from diverse flowers and collected from plant anthers by honey bees (Apis mellifera L.). Bee pollen contains a variety of biomolecules such as essential amino acids, proteins, unsaturated fatty acids, anthocyanins, organic acids (ferulic, pantothenic, etc.), vitamins, minerals (iron, manganese, zinc) and trace elements (Oliveira et al., 2013; Attia et al., 2014). It also contsists of carotenoids, flavonoids and phytosterols (Feás et al., 2012). Bee pollen is regarded as a health promoting food additives with a wide range of therapeutic properties, among which antioxidant, antifungal, antimicrobial, anti-radiation, chemoprotective, chemopreventive, hepatoprotective, and anti-inflammatory activity are the most prominent (Yamaguchi et al., 2006; Pascoal et al., 2014). Bee pollen has been reported to promote animal growth, to improve the quality and security of animal products, to enhance the immunizing function of poultry and to protect the intestinal tract (Liu et al., 2010). The exact composition of bee pollen significantly depends on the plant source as well as other factors such as climate, beekeeper activities and soil type (Morais et al., 2011).

Propolis is a sticky gummy resinous material that worker honeybees (Apis mellifera $\mathrm{L}$.) collect from buds and young shoots of certain trees and shrubs and mix it with wax and salivary enzymes (Greenaway et al., 1990; Aygun et al., 2012). Propolis contains about 300 constituents (Seven et al., 2012) and its chemical properties and composition depend on the various types of pollens, vegetation, from which the honey bee insects have collected the exudates. A detailed analysis of pollen has revealed a wide array of biomolecules including polyphenols (flavonoid aglycones, phenolic acids, aldehydes, ketones, and alcohols), steroids, terpenoids, amino acids and inorganic compounds (Dimov $\boldsymbol{e} t$ al., 1991; Marcucci et al., 2000; Moreno et al., 2000; Trusheva et al., 2006; Gardana et al., 2007; Nolkemper et al., 2010). Moreover, propolis is composed 
of minerals ( $\mathrm{Mg}, \mathrm{K}, \mathrm{Ca}, \mathrm{Cu}, \mathrm{Na}, \mathrm{Mn}, \mathrm{Zn}$ and $\mathrm{Fe}$ ), vitamins $\left(\mathrm{B}_{1}, \mathrm{~B}_{2}, \mathrm{~B}_{6}, \mathrm{C}\right.$ and $\left.\mathrm{E}\right)$, as well as fatty acids and enzymes (Lotfy, 2006). All these bioactive components of propolis contribute to its antibacterial, antiviral, antifungal, antiprotozoal, antimicrobial, analgesic, anti-inflammatory, antioxidant, anaesthetic, cytostatic, immunostimulant and immunomodulatory effects in both human and animal health (Talas and Gulhan, 2009; Seven et al., 2012; Aygun et al., 2012; Eyng et al., 2013; Fan et al., 2013). Propolis administration has been used in poultry diet (Seven, 2008) and according to some reports, propolis may be an effective natural alternative to antibiotic growth promoters in poultry nutrition (Biavatti $\boldsymbol{e}$ al., 2003, Denli et al., 2005; Shalmany and Shivazad, 2006; Seven et al., 2008; Mathivanan et al., 2013; Babaei et al., 2016).

An alternative approach to the administration of subtherapeutic antibiotics in chicken diet represents the use of probiotics (Alkhalf et al., 2010). Probiotics are live, non-pathogenic bacteria that have the ability to contribute to normal health and milieu of the intestinal tract (Giannenas et al., 2012). Among the most compelling advantages of probiotics are no residues in animal production and no antibiotic resistance by consumption (Alkhalf $\boldsymbol{e t}$ al., 2010). The major probiotic strains include Saccharomyces, Lactobacillus, Bacillus, Streptococcus and Aspergillus spp. (Tannock, 2001). The selected microbial strain, preparation method, dosage, condition of animals and the number of viable microorganisms in probiotics are considered to be critical factors affecting the efficiency of probiotics (Panda et al., 2005).

Several studies have emphasized that probiotics in broiler diets have the ability to improve the nutrition, health and growth performance when compared with nonsupplemented diets, being possibly as effective as antibiotic growth promoters (Wallace and Chesson, 1995; Gong et al., 2002; Kalavathy et al., 2003, Mountzouris et al., 2010, Shim et al., 2010).

The focus of the present study was to evaluate the meat performance following the addition of bee pollen and propolis in a combination with probiotic into diet for Ross 308 broiler chicken.

\section{MATERIAL AND METHODS}

\section{Animals and experimental design}

The experiment was realized in the test poultry station of the Slovak University of Agriculture (SUA) in Nitra. The fattening period lasted for 42 days and the animals were kept under the same conditions. The experiment included 180 oneday-old chicks (Ross 308) of mixed sex randomly divided into 3 groups (each containing 60 chickens). The size of pen for one group of chickens was $3.2 \times 2.4$ $\mathrm{m}$. The broiler chickens were reared on breed litter (wood shavings), in a temperature-controlled room; ambient temperature in test poultry station was maintained at $33{ }^{\circ} \mathrm{C}$ during the first week and gradually decreased by $2{ }^{\circ} \mathrm{C}$, and finally fixed at $23{ }^{\circ} \mathrm{C}$ thereafter. The temperature and relative humidity were controlled. Over the entire fattening period, the chickens were provided with ad libitum access to feed (mash form) as well as drinking water and were kept under a constant light regime. Probiotic dosing pattern via drinking water is presented in Table 1.

\section{Table 1 Probiotic dosing pattern via drinking water}

\begin{tabular}{lcc}
\hline Week of age & $\begin{array}{c}\text { Amount of water per day } \\
\text { for 60 chickens (L) }\end{array}$ & $\begin{array}{c}\text { Amount of probiotic pre } \\
\text { day } \\
\text { for 60 chickens (g) }\end{array}$ \\
\hline 1. & 2.49 & 3.3 \\
2. & 3.51 & 3.3 \\
3. & 4.59 & 3.3 \\
4. & 6.69 & 3.3 \\
5. & 8.61 & 3.3 \\
6. & 10.59 & 3.3 \\
\hline
\end{tabular}

Diets were prepared to accommodate the nutrient requirements of broilers following the recommended reference levels (Bulletin of MARD SR, 2005), and broilers were subjected to a two phase feeding programme, starter HYD-01 (1 21 d) and grower HYD-2 (22 - 42 d) diets. The composition of basal diets is presented in Table 2. The starter and grower feed mixtures were produced without any antibiotics and coccidiostatics and were prepared by Biofeed, Inc. (Kolárovo, Slovak Republic). The experimental groups were set up as follows: the control group (C) involved the basal diet without supplementation; the experimental group of chickens (E1) was fed with basal diet plus $400 \mathrm{mg}$ bee pollen extract/ $1 \mathrm{~kg}$ of feed mixture and $3.3 \mathrm{~g}$ probiotic (Lactobacillus fermentum) added daily to the drinking water and chicks in experimental group E2 were fed with a complete feed mixture plus $400 \mathrm{mg}$ propolis extract/1 $\mathrm{kg}$ of feed mixture and $3.3 \mathrm{~g}$ probiotic (Lactobacillus fermentum) added daily to the drinking water.
Table 2 Composition of feed mixtures

\begin{tabular}{|c|c|c|}
\hline Ingredients (\%) & $\begin{array}{c}\text { Starter (HYD-01) } \\
\left(1^{\text {st }}-21^{\text {st }} \text { day of age }\right)\end{array}$ & $\begin{array}{c}\text { Grower (HYD-02) } \\
\left(22^{\text {nd }}-42^{\text {th }} \text { day of age }\right)\end{array}$ \\
\hline Maize & 36.00 & 41.00 \\
\hline Wheat & 34.00 & 34.00 \\
\hline $\begin{array}{l}\text { Soybean meal ( } 48 \% \\
\text { N) }\end{array}$ & 21.20 & 18.60 \\
\hline Fish meal $(71 \% \mathrm{~N})$ & 3.90 & 2.10 \\
\hline Dried blood & 1.20 & 1.20 \\
\hline Ground limestone & 1.05 & 1.10 \\
\hline $\begin{array}{l}\text { Monocalcium } \\
\text { phosphate }\end{array}$ & 1.00 & 0.75 \\
\hline Sodium bicarbonate & 0.14 & 0.20 \\
\hline Fodder salt & 0.11 & 0.10 \\
\hline Methionine & 0.15 & 0.23 \\
\hline Lysine & 0.05 & 0.06 \\
\hline $\begin{array}{l}\text { Palm kernel oil } \\
\text { Bergafat }\end{array}$ & 0.70 & 0.16 \\
\hline $\begin{array}{l}\text { Premix Euromix BR } \\
0.5 \%\end{array}$ & 0.50 & 0.50 \\
\hline \multicolumn{3}{|c|}{ Nutrient composition $\left[\mathrm{g} . \mathrm{kg}^{-1}\right]$} \\
\hline Linoleic acid & 13.52 & 14.14 \\
\hline Fibre & 30.29 & 29.83 \\
\hline Crude protein & 211.38 & 190.56 \\
\hline Ash & 25.81 & 20.32 \\
\hline $\mathbf{C a}$ & 8.17 & 7.25 \\
\hline $\mathbf{P}$ & 6.79 & 5.75 \\
\hline Mg & 1.43 & 1.41 \\
\hline $\mathrm{ME}_{\mathrm{N}}\left(\mathrm{MJ}_{\mathrm{k}} \mathrm{kg}^{-1}\right)$ & 12.03 & 12.04 \\
\hline
\end{tabular}

*active substances per kilogram of premix: vitamin A 2,500,000 IU; vitamin $\mathrm{D}_{3} 800,000 \mathrm{IU}$; vitamin E 50,000 mg; ascorbic acid 50,000 mg; niacin 12,000 $\mathrm{mg}$; D-pantothenic acid 3,000 mg; riboflavin 1,800 mg; pyridoxine $1,200 \mathrm{mg}$; methadione $800 \mathrm{mg}$; thiamine $600 \mathrm{mg}$; folic acid $400 \mathrm{mg}$; choline 100,000 mg; biotin $40 \mathrm{mg}$; cobalamin $10.0 \mathrm{mg}$; betaine 50,000 mg; Mn 20,000 mg; Zn 16,000 $\mathrm{mg}$; Fe 14,000 mg; I $200 \mathrm{mg}$; Cu 2,400 mg; Co $80 \mathrm{mg}$; Se $50 \mathrm{mg}$. ME metabolizable energy corrected for nitrogen equilibrium.

\section{Characterization of probiotic preparation applied in experiment}

In the experiment, two-component probiotic preparation "Propoul" containing probiotic microorganism Lactobacillus fermentum $\left(1.10^{9} \mathrm{CFU}\right.$ per $1 \mathrm{~g}$ of bearing medium) and a potentiating component (maltodextrin and oligofructose) was used. The probiotic preparation was supplied by IPC Ltd. (Košice, Slovak Republic).

\section{Bee pollen and propolis extracts preparation}

Bee pollen and propolis extracts used in the experiment came from the Slovak Republic. The extracts were prepared from minced bee pollen and propolis in $80 \%$ ethanol inside of $500 \mathrm{ml}$ flasks, according to Krell (1996). The extraction took place in a water bath at $80{ }^{\circ} \mathrm{C}$ under reflux cooler for one hour. Subsequently the extracts were cooled and centrifuged. The obtained supernatants were evaporated in a rotary vacuum evaporator at $40-50^{\circ} \mathrm{C}$, and then weighed. Finally, the residues in an appropriate amount (depending on addition of supplement per $\mathrm{kg}$ of feed) was dissolved in ethanol and applied to the feed mixture through a bearing medium.

\section{Slaughter and measurements}

At 42 days of age, 30 chickens of mixed sex (15 0 and 15 q) were selected from each group based on the average weight, then weighed and slaughtered at the experimental slaughterhouse of Department of Animal Products Evaluation and Processing (SUA, Nitra). The chickens were slaughtered by conventional neck cut, bled, feathers removed, and eviscerated.

Examined parameters in experiment were as follows: live body weight (BW) (g) at the and fattening period; carcass weight $(\mathrm{CW})(\mathrm{g})$; giblets weight $(\mathrm{g})$; beast part weight (g); thigh part weight $(\mathrm{g})$; abdominal fat weight $(\mathrm{g})$; total weight of internal fats (heart, gastric, and abdominal) (g); carcass yield (\%); breast part yield (\% of $\mathrm{CW})$; thigh part yield (\% of $\mathrm{CW})$; valuable carcass parts (breast and thigh) yield (\% of $\mathrm{CW})$.

\section{Statistical analysis}

Statistical analysis was calculated using ANOVA and SAS software with the Enterprise Guide 4.2 application (version 9.3, SAS Institute Inc., USA, 2008). Results were reported as mean \pm standard deviation. Statistical significance was 
calculated using the t-test. Differences between the groups were considered significant at $\mathrm{P} \leq 0.05$.

\section{RESULTS AND DISCUSSION}

The use of growth promoters as antibiotics for poultry production has been banned in many countries, which in turn comes hand in hand with their prohibition as possible protective agents against infectious diseases and subsequently an increased economic loss for the poultry industry (Peric $\boldsymbol{e t}$ al., 2009). Therefore, many researchers have tried to search for natural feed additives such as bee products as propolis, bee pollen and probiotics to be used in the poultry diet in order to reduce possible harmful effects (Hegazi et al., 2012).

The effect of bee supplements in feed as bee pollen and propolis in combination with probiotic on meat performance of Ross 308 broiler chickens is shown in Table 3.

Table 3 Effect of natural feed supplements on meat performance and carcass characteristics of broiler chickens

\begin{tabular}{lccc}
\hline ParameterlGroup & C & E1 & E2 \\
\hline Live BW (g) & $2,270.2 \pm 107.88^{\mathrm{a}}$ & $2,401.7 \pm 144.5^{\mathrm{b}}$ & $2,358 \pm 157.16^{\mathrm{ab}}$ \\
CW (g) & $1,629.8 \pm 73.65^{\mathrm{a}}$ & $1,714 \pm 82.74^{\mathrm{b}}$ & $1,688 \pm 121.07^{\mathrm{ab}}$ \\
Giblets (g) & $152.08 \pm 19.83$ & $162.18 \pm 17.31$ & $159.12 \pm 16.33$ \\
Breast part (g) & $621.34 \pm 52.22^{\mathrm{a}}$ & $667.48 \pm 43.21^{\mathrm{b}}$ & $641.94 \pm 53.18^{\mathrm{ab}}$ \\
Thigh part (g) & $471.74 \pm 45.11$ & $474.38 \pm 47.79$ & $481.39 \pm 47.04$ \\
Abdominal fat (g) & $22.14 \pm 4.77$ & $25.01 \pm 5.63$ & $24.81 \pm 6.81$ \\
$\begin{array}{l}\text { Total internal fats (g) } \\
\text { Carcass yield (\%) }\end{array}$ & $31.64 \pm 4.94$ & $34.52 \pm 6.55$ & $32.79 \pm 8.94$ \\
$\begin{array}{l}\text { Breast part yield (\% } \\
\text { of CW) }\end{array}$ & $38.54 \pm 1.41$ & $78.17 \pm 1.65$ & $78.33 \pm 0.86$ \\
$\begin{array}{l}\text { Thigh part yield (\% } \\
\text { of CW) }\end{array}$ & $28.93 \pm 2.42$ & $27.64 \pm 1.88$ & $28.5 \pm 1.51$ \\
$\begin{array}{l}\text { Valuable parts yield } \\
\text { (\% of CW) }\end{array}$ & $67 \pm 2.11^{\mathrm{ab}}$ & $66.61 \pm 2.02^{\mathrm{b}}$ & $66.51 \pm 1.82^{\mathrm{b}}$ \\
\hline
\end{tabular}

Note: Values are given as mean $\pm \mathrm{SD}$ (standard deviation); $\mathrm{n}=30 ; \mathrm{C}=$ contro group; E1, E2 = experimental groups; ${ }^{\text {a, b }}=$ means within the

same row with different superscripts differs significantly $(\mathrm{P} \leq 0.05) ; \mathrm{BW}=$ body weight CW $=$ carcass weight .

According to the data obtained, significant differences $(\mathrm{P} \leq 0.05)$ in live body weight and carcass weight were found between broilers fed a basal diet (C) and those having bee pollen plus probiotic in their diets (E1) $(2,401.7$ and 1,714 g vs. $2,270.2$ and 1,629.8 g, respectively). Both live body weight and carcass weight in E1 group were the highest among the groups. The increase in carcass weight is in large part due to the increasing in body weight.

It is also apparent from this table that $\mathrm{C}$ group had significantly $(\mathrm{P} \leq 0.05)$ lower breast part weight $(621.34 \mathrm{~g})$ compared with group E1 (667.48 g). Contrary to expectations, it was a little disappointing that the analysis did not confirm any differences $(\mathrm{P}>0.05)$ between the groups with respect to the other carcass characteristics (giblets weight, thigh part weight, abdominal fat weight, total weight of internal fat, carcass yield, breast part yield, thigh part yield and valuable parts yield). Our results are also consistent with the findings of other authors (Alloui et al., 2012; Mokhtari et al., 2015; Odefemi, 2016; Pourakbari et al., 2016) that revealed no significant effect $(\mathrm{P}>0.05)$ on the breast and thigh percentage of broilers fed diet containing probiotic.

On the other hand, bee pollen and probiotic supplementation has shown to be the most favourable among the dietary treatments regarding meat performance and carcass characteristics of broilers. Among the most noteworthy parameters affected positively by this supplement may be mentioned the live body weight, carcass weight and breast part weight. These improvements may be due to the nutritive value of bee pollen as a rich source of protein, EAAs, MUFA and PUFA, and the presence of minerals and the other micronutrients with a positive impact on the broiler health and metabolism. These results would also seem to suggest that propolis supplementation with probiotic (E2) had hardly any effect on performance and carcass characteristics of broiler chickens Ross 308. Despite this, it cannot be ignored that there was a tendency for propolis in combination with probiotic $(\mathrm{E} 2)$ to increase $(\mathrm{P}>0.05)$ the parameters of meat performance compared with $\mathrm{C}$ group. It is difficult to explain this result, but it might be related to components in propolis such as benzoic and 4-hydroxybenzoic acid, which may improve the digestibility of such nutrients as protein and ash (Seven et al., 2012). Another possible explanation for this might be that propolis contains substances with antimicrobial potential, also resulting in a better intestinal digestion and absorption (Shaddel-Tili et al., 2017). Naturally, there may be other possible explanations. Disappointingly, the findings hardly show any synergic effect of propolis and probiotic (E2).
Hardly any studies have been published on combined effect of bee products and probiotics. Adhikari et al. (2017) found decreased live body weight $(\mathrm{P}>0.05)$ of broilers Cobb 500 fed with different amounts of native bee pollen plus probiotics (commercial preparation containing Saccharomyces cerevisiae, S. boulardii, Lactobacillus acidophilus and Propionibacterium freudenreichii). Another study (Daneshmand et al., 2015) evaluated the effects of propolis (200 mg. $\mathrm{kg}^{-1}$ of feed) and probiotic (450 mg. $\mathrm{kg}^{-1}$ of feed) alone or their combination (200 and $450 \mathrm{mg} \cdot \mathrm{kg}^{-1}$, respectively) on performance of male broilers (Ross 308). A commercial product containing L. acidophilus, L. casei, Bifidobacterium bifidum and Enterococcus faecium was used as the source for the probiotic. However, none of the supplements affected $(\mathrm{P}>0.05)$ body weight at $42 \mathrm{~d}$ of age in comparison with the control group. The improved weight gain might be caused by the nutrient composition of bee pollen along with their antioxidant activities and health protection (Szczêsna, 2007; Šarić et al., 2009) as well as by maintaining the intestinal microbial balance of gastrointestinal tract, the activity of digestive enzymes which may help to enhance the production performance (Tortuero and Fernandez, 1995; Jin et al., 1997). The study of Klarić (2014) demonstrated improved performance $(\mathrm{P} \leq 0.05)$ of broilers after both bee pollen and propolis supplementation (separately or in combination). Regarding the probiotics, there is a considerable variation in the available studies focused on the effect of probiotic strains on the performance of broiler chickens. The inconsistent and contradictory reports are due to many factors that affect the response of broiler chickens to probiotics. The factors include method and duration of probiotic feeding, nature and dose of the administered strains and their persistence, variations in the physiological condition of the animal, the actual microbial balance in the chicken gut, overall diet, age and sex of chicken, as well as overall farm hygiene, and environmental stress factors (Zhou $\boldsymbol{e t}$ al., 2010; Aliakbarpour et al., 2012). Similarly, findings obtained in other reports showed that probiotics, either as a single strain or as a mixture of strains, promoted $(\mathrm{P} \leq 0.05)$ the performance and carcass characteristics of broilers (Khaksefidi and Rahimi, 2005; Alkhalf et al., 2010; Zhou et al., 2010; Aliakbarpour et al., 2012; Naseem et al., 2012; Taklimi et al., 2012; Ghahri et al., 2013; Shokryazdan et al., 2017).

\section{CONCLUSION}

This study was designed to determine the effect of dietary supplementation with bee pollen, propolis, and probiotic (Lactobacillus fermentum) on the meat performance and carcass characteristics of broiler chickens. The findings of the work on meat performance and carcass characteristics of chickens indicated that bee pollen in combination with probiotic was the most suitable feed supplement. Among the most noteworthy parameters affected positively $(\mathrm{P} \leq 0.05)$ by this supplement in comparison with control may be mentioned the breast part weight. Moreover, it seems likely that there was synergistic effect of bee pollen and probiotic manifested by higher live body weight and carcass weight $(\mathrm{P} \leq 0.05)$ in comparison with the control.

Present results would also seem to suggest that propolis supplementation with probiotic had effects on meat performance and carcass characteristics of Ross 308 broiler chicken.

Acknowledgments: This work was supported by KEGA no. 027SPU-4/2019

\section{REFERENCES}

ABDEL-KAREEM, A. A. A., EL-SHEIKH, T. M. 2015. Impact of supplementing diets with propolis on productive performance, egg quality traits and some haematological variables of laying hens. Journal of Animal Physiology and Animal Nutrition, 101(3), 441-448. https://doi.org/10.1111/jpn.12407 ABO OMAR, J., HEJAZI, A., BADRAN, R. 2016. Performance of Broilers Supplemented with Natural Herb Extract. Open Journal of Animal Sciences, 06(1), 68-74. http://dx.doi.org/10.4236/ojas.2016.61009

ABOU-ZEID, A. E, EL-DAMARAWY, S. Z, MARIEY, Y. A, EL-KASASS, S M. 2015. Effect of dietary propolis supplementation on performance and activity of antioxidant enzymes in broiler chickens. Egyptian Journal of Nutrition and Feeds, 18(2), 391-400.

ADHIKARI, A., ADHIKARI, B., DHUNGANA, S. K., LEE, KO-EUN, ARUN GC, KANG, SANG-MO, ACHARYA, M., POUDEL, S., LEE, IN-JUNG. 2017 Effect of Bee Pollen and Probiotics on Growth Performance, Organs, and Thigh Meat pH of Broiler Cobb 500. In Journal of Microbiology, Biotechnology and Food Sciences, 7(1), 79-82. https://doi.org/10.15414/imbfs.2017.7.1.79-82

ALIAKBARPOUR, H. R., CHAMANI, M., RAHIMI, G., SADEGHI, A. A., QUJEQ, D. 2012. The Bacillus subtilis and Lactic Acid Bacteria Probiotics Influences Intestinal Mucin Gene Expression, Histomorphology and Growth Performance in Broilers. Asian-Australasian Journal of Animal Sciences, 25(9), 1285-1293. https://doi.org/10.5713/ajas.2012.12110

ALKHALF, A., ALHAJ, M., AL-HOMIDAN, I. 2010. Influence of probiotic supplementation on blood parameters and growth performance in broiler chickens. Saudi Journal of Biological Sciences, 17(3), 219-225. http://dx.doi.org/10.1016/j.sjbs.2010.04.005 
ALlOUI, N., CHAFAI, S., ALLOUI, M. N. 2012. Effect of probiotic feed additives on broiler chickens health and performance. Online Journal of Animal and Feed Research, 2 (1), 104-107.

ATTIA, Y. A, ABD AL-HAMID, A. E, IBRAHIM, M. S, AL-HARTHI, M. A BOVERA, F., ELNAGGAR, A. SH. 2014. Productive performance, biochemical and hematological traits of broiler chickens supplemented with propolis, bee pollen, and mannan oligosaccharides continuously or intermittently. Livest Science, 164, 87-95. https://doi.org/10.1016/j.livsci.2014.03.005

AYGUN, A., SERT, D., COPUR, G. 2012. Effects of propolis on eggshell microbial activity, hatchability, and chick performance in Japanese quai (Coturnix coturnix japonica) eggs. Poultry Science, 91(4), 1018-1025 https://doi.org/10.3382/ps.2011-01944

BABAEI, S., RAHIMI, S., TORSHIZI, M. A. K., TAHMASEBI, G. KHALEGHI MIRAN, S. N. 2016. Effects of propolis, royal jelly, honey and bee pollen on growth Performance and immune system of Japanese quails. Veterinary Research Forum, 7(1), 13-20.

BIAVATTI, M.W., BELLAVER, M.H., VOLPATO, L., COSTA, C. BELLAVER, C. 2003. Preliminary studies of alternative feed additives for broilers: Alternanthera brasiliana extract, propolis extract and linseed oil. Revista Brasileira de Ciência Avícola, 5(2), 147-151. https://doi.org/10.1590/s1516635x2003000200009

BULLETIN of MARD SR (Ministry of Agriculture and Rural Development of the Slovak Republic). 2005. Decree of Ministry of Agriculture and Rural Development of the Slovak Republic no. 2080/2005-100 of 23 March 2005 changing and amending Decree of Ministry of Agriculture and Rural Development of the Slovak Republic no. 1497/1/1997-100 of 7 October 1997 regulating feed materials for the manufacture of feed mixtures and farm feeds.

DANESHMAND, A., SADEGHI, G. H., KARIMI, A., VAZIRY, A., IBRAHIM, S. A. 2015. Evaluating complementary effects of ethanol extract of propolis with the probiotic on growth performance, immune response and serum metabolites in male broiler chickens. Livestock Science, 178, 195-201. https://doi.org/10.1016/j.livsci.2015.04.012

DENLI, M., CANKAYA, S., SILICI, S., OKAN, F., ULUOCAK, A.N. 2005. Effect of dietary addition of Turkish propolis on the growth performance, carcass characteristics and serum variables of quail (Coturnix coturnix japonica). AsianAustralasian Journal of Animal Sciences, 18(6): 848-854. https://doi.org/10.5713/ajas.2005.848

DIMOV, V., IVANOVSKA, N., MANOLOVA, N., BANKOVA, V., NIKOLOV, N., POPOV, S. 1991. Immuno-modulatory action of propolis Influence on anti-infections protection and macrophage function. Apidologie, 22(2), 155-162. https://doi.org/10.1051/apido:19910208

EYNG, C., MURAKAMI, A. E., PEDROSO, R. B., SILVEIRA, T. G. V., LOURENÇO, D. A. L., GARCIA, A. F. Q. M. 2013. Crude propolis as an immunostimulating agent in broiler feed during the starter phase. Semina: Ciências Agrárias, 34(5), 2511. https://doi.org/10.5433/1679 0359.2013v34n5p2511

FAN, Y., LU, Y., WANG, D., LIU, J., SONG, X., ZHANG, W., ZHAO, X. NGUYEN, L., HU, Y. 2013. Effect of epimedium polysaccharide-propolis flavone immunopotentiator on immunosuppression induced by cyclophosphamide in chickens. Cellular Immunology, 281(1), 37-43. http://dx.doi.org/10.1016/j.cellimm.2013.01.008

FARAG, S. A.,. EL-RAYES, T. K 2016. Research Article Effect of Bee-pollen Supplementation on Performance, Carcass Traits and Blood Parameters of Broiler Chickens. Asian Journal of Animal and Veterinary Advances, 11(3), 168177. https://doi.org/10.3923/ajava.2016.168.177

FEÁS, X., VÁZQUEZ-TATO, M. P., ESTEVINHO, L., SEIJAS, J. A. IGLESIAS, A. 2012. Organic Bee Pollen: Botanical Origin, Nutritional Value, Bioactive Compounds, Antioxidant Activity and Microbiological Quality. Molecules, 17(7), 8359-8377. http://dx.doi.org/10.3390/molecules17078359

GARDANA, C., SCAGLiANTI, M., PIETTA, P., SIMONETTI, P. 2007. Analysis of the polyphenolic fraction of propolis from different sources by liquid chromatography-tandem mass spectrometry. Journal of Pharmaceutical and Biomedical Analysis, 45(3), 390-399. https://doi.org/10.1016/j.jpba.2007.06.022 GHAHRI, H., TOLOEI, T., SOLEIMANI, B. 2013. Efficacy of Antibiotic, Probiotic, Prebiotic and Synbiotic on Growth Performance, Organ Weights, Intestinal Histomorphology and Immune Response in Broiler Chickens. Global Journal of Animal Scientific Research, 1(1), 25-41.

GIANNENAS, I., PAPADOPOULOS, E., TSALIE, E., TRIANTAFILLOU, E. HENIKL, S., TEICHMANN, K., TONTIS, D. 2012. Assessment of dietary supplementation with probiotics on performance, intestinal morphology and microflora of chickens infected with Eimeria tenella. Veterinary Parasitology, 188(1-2), 31-40. http://dx.doi.org/10.1016/j.vetpar.2012.02.017

GONG, J., FORSTER, R. J., YU, H., CHAMBERS, J. R., WHEATCROFT, R., SABOUR, P. M., CHEN, S. 2002. Molecular analysis of bacterial populations in the ileum of broiler chickens and comparison with bacteria in the cecum. FEMS Microbiology Ecology, 41(3), 171-179. https://doi.org/10.1111/j.15746941.2002.tb00978.x

GRASHORN, M. A. 2007. Functionality of poultry meat. The Journal of Applied Poultry Research, 16 (1), 99-106. https://doi.org/10.1093/japr/16.1.99
GREENAWAY, W., SCAYSBROOK, T., WHATLEY, F. R. 1990. The composition and plant origins of propolis. Bee World, 71(3), 107-118 https://doi.org/10.1080/0005772X.1990.11099047

HAŠČÍK, P., TREMBECKÁ, L., BOBKO, M., KAČÁNIOVÁ, M., ČUBOŇ, J., KUNOVÁ, S., BUČKO, O. 2016. Effect of diet supplemented with propolis extract and probiotic additives on performance, carcass characteristics and meat composition of broiler chickens. Potravinarstvo, 10(1), 223-231. https://doi.org/10.5219/581

HEGAZI, A., ABDOU, A. M., ALLAH, F. A. 2012. Egyptian propolis 9- Its effect on chicken productivity and immune response against Newcastle disease vaccine. British Journal of Poultry Science, 1(3), 25-30. https://doi.org/10.5829/idosi.bips.2012.1.3.8147

JIN, L. Z., HO, Y. W., ABDULLAH, N., JALALUDIN, S. 1997. Probiotics in poultry: Modes of action. World's Poultry Science Journal, 53(4), 351-368. https://doi.org/10.1079/WPS19970028

KAHRAMAN, T., ISSA, G., ALTUNATMAZ, S. S, KAHRAMAN, B. B., AKSU, F., AYDIN, A., AKSU, H. 2016. Effects of oregano essential oil, grapefruit seed extract and their combination on the growth and survival of Salmonella typhimurium and Listeria monocytogenes in poultry fillets under modified atmosphere packaging. Slovenian Veterinary Research, 53 (1), 5-12.

KALAVATHY, R., ABDULLAH, N., JALALUDIN, S., HO, Y. W. 2003 Effects of Lactobacillus cultures on growth performance, abdominal fat deposition, serum lipids and weight of organs of broiler chickens. British Poultry Science, 44(1), 139-144. https://doi.org/10.1080/0007166031000085445

KARADAS, F, ERDOGAN, S, KOR, D, OTO, G., ULUMAN, M. 2016. The Effects of Different Types of Antioxidants (Se, Vitamin E and Carotenoids) in Broiler Diets on the Growth Performance, Skin Pigmentation and Liver and Plasma Antioxidant Concentrations. Brazilian Journal of Poultry Science, 18(1), 101-116. http://dx.doi.org/10.1590/18069061-2015-0155

KHAKSEFIDI, A., RAHIMI, S. H. 2005. Effect of Probiotic Inclusion in the Diet of Broiler Chickens on Performance, Feed Efficiency and Carcass Quality. Asian-Australasian Journal of Animal Sciences, 18(8), 1153-1156. https://doi.org/10.5713/ajas.2005.1153

KHATTAK, F. M., PASHA, T. N., HAYAT, Z., MAHMUD, A. 2006. Enzymes in poultry nutrition. Journal of Animal and Plant Science, 16(1-2), 1-7.

KLARIC, I. 2014. Production and Health Effects of Propolis and Bee Pollen as Food Additives in Broilers Feeding. Poljoprivreda, 20 (2), 61-64.

KLARIĆ, I., DOMAĆINOVIĆ, M., ŠERIĆ, V., MIŠKULIN, I., PAVIĆ, M., PARADINOVIĆ, K. 2018. Effects of Bee Pollen and Propolis on Performance, Mortality, and Some Haematological Blood Parameters in Broiler Chickens Slovenian Veterinary Research, 55(1), 23-34. https://doi.org/10.26873/svr-3852018

KLECZEK, K., MAJEWSKA, K., MAKOWSKI, W., MICHALIK, D. 2012. The effect of diet supplementation with propolis and bee pollen on the physicochemical properties and strength of tibial bones in broiler chickens. Archives Animal Breeding, 55 (1), 97-103. https://doi.org/10.5194/aab-55-972012

KRELL, R. 1996. Value-Added products from bee keeping. Rome: Food and Agriculture Organization of the United Nations. 395 p. ISBN 92-5-103819-8.

LIU, G., YAN, W., ZENG, Z. 2010. Application of bee pollen on the Gallus feed. Journal of Bee, 3, 22-29.

LOTFY, M. 2006. Biological activity of bee propolis in health and disease. Asian Pacific Journal of Cancer Prevention, 7: 22-31.

MARCUCCI, M. C., FERRERES, F., CUSTODIO, A. R., FERREIRA, M. M. C., BANKOVA, V. S., GARCIA-VIGUERA, C., BRETZ, W. A. 2000 Evaluation of phenolic compounds in Brazilian propolis from different geographic regions. Zeitschrift für Naturforschung C, 55 (1-2), 76-81. https://doi.org/10.1515/znc-2000-1-215

MATHIVANAN, V., SHAH, G. H., MANZOOR, M., MIR, G. M. SELVISABHANAYAKAM. 2013. A review on propolis- as a novel folk medicine. Indian Journal of Science, 2(3), 23-30.

MOKHTARI, R. YAZDANI, A., KASHFI, H. 2015. The effects of different growth promoters on performance and carcass characteristics of broiler chickens Journal of Veterinary Medicine and Animal Health, 7(8), 271-277. https://doi.org/10.5897/jvmah2015.0394

MORAIS, M., MOREIRA, L., FEAS, X., ESTEVINHO, L. M. 2011. Honeybeecollected pollen from five Portuguese Natural Parks: palynological origin phenolic content antioxidant properties and antimicrobial activity. Food and Chemical Toxicology, 49(5),

http://dx.doi.org/10.1016/j.fct.2011.01.020

MORENO, M. I. N., ISLA, M. I., SAMPIETRO, A. R., VATTUONE, M. A 2000. Comparison of the free radical-scavenging activity of propolis from several regions of Argentina. Journal of Ethnopharmacology, 71(1-2), 109-114. https://doi.org/10.1016/S0378-8741(99)00189-0

MOUNTZOURIS, K. C., TSITRSIKOS, P., PALAMIDI, I., ARVANITI, A., MOHNL, M., SCHATZMAYR, G., FEGEROS, K. 2010. Effects of probiotic inclusion levels in broiler nutrition on growth performance, nutrient digestibility, plasma immunoglobulins, and cecal microflora composition. Poultry Science, 89(1), 58-67. http://dx.doi.org/10.3382/ps.2009-00308 
NASEEM, S., RAHMAN, S. U., SHAFEE, M., SHEIKH, A. A., KHAN, A. 2012. Immunomodulatory and Growth-Promoting Effect of a Probiotic Supplemented in the Feed of Broiler Chicks Vaccinated Against Infectious Bursal Disease. Brazilian Journal of Poultry Science, 14(2), 109-113. https://doi.org/10.1590/s1516-635x2012000200004

NOLKEMPER, S., REICHLING, J., SENSCH, K. H., SCHNITZLER, P. 2010 Mechanism of herpes simplex virus type 2 suppression by propolis extracts. Phytomedicine, 17(2), 132-138. https://doi.org/10.1016/j.phymed.2009.07.006 ODEFEMI, T. R. 2016. Performance response and carcass characteristics of broilers fed dietary antibiotics, probiotics and prebiotics. European Journal of Agriculture and Forestry Research, 4(1), 27-36.

OLIVEIRA, M. C., SILVA, D. M., LOCH, F. C., MARTINS, P. C., DIAS, D. M. B., SIMON, G. A. 2013. Effect of bee pollen on the immunity and tibia characteristics in broilers. Brazilian Journal of Poultry Science, 15(4), 323-328. http://dx.doi.org/10.1590/s1516-635x2013000400006

PANDA, A. K., RAJU, M. V. L. N., RAMA RAO, S. V., SHARMA, S. R. 2005 The influence of supplementation of lactobacillus sporogenes on the performance of broilers. Indian Journal of Animal Nutrition, 22(1), 37-40.

PASCOAL, A., RODRIGUES, S., TEIXEIRA, A., FEAS, X., ESTEVINHO, L. M. 2014. Biological activities of commercial bee pollens: Antimicrobial, antimutagenic, antioxidant and anti-inflammatory. Food and Chemical Toxicology, 63, 233-239. http://dx.doi.org/10.1016/j.fct.2013.11.010

PERIC, I., ZIKIE, D., LUKIC, M. 2009. Application of alternative growth promoters in broiler production. Biotechnology in Animal Husbandry, 25(5-6-1), 387-397. https://doi.org/10.2298/bah0906387p

POURAKBARI, M., SEIDAVI, A., ASADPOUR, L., MARTÍNEZ, A. 2016. Probiotic level effects on growth performance, carcass traits, blood parameters, cecal microbiota, and immune response of broilers. Anaisda Academia Brasileira de Ciências, 88(2), 1011-1021. https://doi.org/10.1590/0001-3765201620150071 PROBST, Y. 2009. Nutrient composition of chicken meat. Australian Government Publication No. 08/210. Project No. PRJ-001502. Rural Industries Research and Development Corporation, Kingston, Australian Capital Territory, Australia.

RAMA RAO, S.V., RAJU, M.V. L. N., PANDA, A., REDDY, M. R. 2006 Sunflower seed meal as a substitute for soybean meal in commercial broiler chicken diets. British Poultry Science, 47(5), 592-598. https://doi.org/10.1080/00071660600963511

RICKE, S. C. 2018. Impact of Prebiotics on Poultry Production and Food Safety. Yale Journal of Biology and Medicine, 91, 151-159.

SAS. 2008. 9.3 Enhanced Logging Facilities. Cary, NC: SAS Institute Inc.

SEVEN, P. T. 2008. The effect of dietary Turkish propolis and vitamin C on performance, digestibility, egg production and egg quality in laying hens under different environmental temperatures. Asian-Australasian Journal of Animal Sciences, 21(8), 1164-117. https://doi.org/10.5713/ajas.2008.70605

SEVEN, P. T., SEVEN, I., YILMAZ, M., SIMSSEK, Ü. G. 2008. The effects of Turkish Propolis on growth and carcass characteristics in broilers under heat stress. Animal Feed Science and Technology, 146(1-2), 137-148. https://doi.org/10.1016/j.anifeedsci.2007.11.003

SEVEN, P. T., YILMAZ, S., SEVEN, I., KELESTEMUR, G. T. 2012. The effects of propolis in animals exposed oxidative stress. Oxidative Stress Environmental Induction and Dietary Antioxidants, In Tech., 267-288. https://doi.org/10.5772/34850

SEVEN, I., AKSU, T., SEVEN, P. T. 2012. The effects of propolis and vitamin C supplemented feed on performance, nutrient utilization and carcass characteristics in broilers exposed to lead. Livestock Science, 148(1-2), 10-15 https://doi.org/10.1016/j.livsci.2012.05.001

SEVEN, I., ŞİMŞEK, Ü. G., GÖKÇE, Z., SEVEN, P. T., ARSLAN, A., YILMAZ, Ö. 2014. The effects of royal jelly on performance and fatty acid profiles of different tissues in quail (Coturnix coturnix japonica) reared under high stocking density. Turkish Journal of Veterinary and Animal Sciences, 38(3), 271-277. https://doi.org/10.3906/vet-1303-62

SHADDEL-TILI, A., ESHRATKHAN, B., KOUZEHGARI, H., GHASEMISADABADI, M. 2017. The effect of different levels of propolis in diets on performance, gastrointestinal morphology and some blood parameters in broiler chickens. Bulgarian Journal of Veterinary Medicine, 20(3), 215-224. https://doi.org/10.15547/bjvm.986

SHALMANY, S. K., SHIVAZAD, M. 2006. The effect of diet propolis supplementation on Ross broiler chick's performance. International Journal of Poultry Science, 5(1), 84-88. https://doi.org/10.3923/ijps.2006.84.88

SHIM, Y. H., SHINDE, P. L., CHOI, J. Y., KIM, J. S., SEO, D. K., PAK, J. I., CHAE, B. J., KWON, I. K. 2010. Evaluation of multimicrobial probiotics produced by submerged liquid and solid substrate fermentation methods in broilers. Asian-Australasian Journal of Animal Sciences, 23(4), 521-529. https://doi.org/10.5713/ajas.2010.90446

SHOKRYAZDAN, P., JAHROMI, M. F., LIANG, J. B., RAMASAMY, K., SIEO, CH. CH., HO, Y. W. 2017. Effects of a Lactobacillus salivarius mixture on performance, intestinal health and serum lipids of broiler chickens. PLOS ONE, 12(5), e0175959. https://doi.org/10.1371/journal.pone.0175959

SOLA-OJO, F. E., ADEYEMI, K. D., TOYE, A. A., BOLU, S. A., FAYEYE, T. R., ANNONGU, A. A., GARBA, S. O., KARIM, R. O. 2013. Performance, carcass profile and oxidative stability of broiler chickens fed processed baobab seed meal. Bulletin of Environment, Pharmacology and Life Sciences, 2(11), 94 99.

SZCZÊSNA, T. 2007. Concentration of selected elements in honeybee-collected pollen. Journal of Apicultural Science, 51(1), 5-13

ŠARIĆ, A., BALOG, T., SOBOCANEC, S., KUSIC, B., SVERKO, V., RUSAK, G., LIKIC, S., BUBALO, D., PINTO, B., REALI, D., MAROTTI, T. 2009 Antioxidant effects of flavonoid from Croatian Cystus incanus L. rich bee pollen. Food and Chemical Toxicology, 47(3), 547-554 http://dx.doi.org/10.1016/j.fct.2008.12.007

TAKLIMI, S. M. S. M., LOTFOLLAHIAN, H., SHAHNE, A. Z., MIRZAEI, F., ALINEJAD, A. 2012. Study on efficacy of probiotic in broiler chickens diet. Agricultural Sciences, 3(1), 5-8. https://doi.org/10.4236/as.2012.31002

TALAS, Z. S., GULHAN, M. F. 2009. Effects of various propolis concentrations on biochemical and hematological parameters of rainbow trout (Oncorhynchus mykiss). Ecotoxicology and Environmental Safety, 72(7), 1994-1998. https://doi.org/10.1016/i.ecoenv.2009.04.011

TANNOCK, G. W. 2001. Probiotics and probiotics: Scientific aspects. Caister Academic Press: the 12th European Symposium on Poultry Nutrition, Veldhoven, The Netherlands: WPSA Dutch Branch, pp: 193-201.

TOGHYANI, M., TOGHYANI, M., TABEIDIAN, S. A. 2011. Effect of probiotic and prebiotic as antibiotic growth promoter substitutions on productive and carcass traits of broiler chicks. 2011 International Conference on Food Engineering and Biotechnology IPCBEE vol. 9.

TORTUERO, F., FERNÁNDEZ, E. 1995. Effects of inclusion of microbial cultures in barley-based diets fed to laying hens. Animal Feed Science and Technology, 53(3-4), 255-265. http://dx.doi.org/10.1016/0377-8401(94)00747-W TRUSHEVA, B., POPOVA, M., BANKOVA, V., SIMOVA, S., MARCUCCI, M.C., MIORIN, P.L. DA, ROCHA PASIN, F., TSVETKOVA, I., 2006 Bioactive constituents of Brazilian red propolis. Evidence-Based Complementary and Alternative Medicine - Oxford, 3(2), 249-254. https://doi.org/10.1093/ecam/nel006

WALlACE, J. R., CHESSON, A. 1995. Biotechnology in Animal Feeds and Animal Feeding. Weinheim :Wiley VCH Verlag GmbH.

YAMAGUCHI, M., HAMAMOTO, R. UCHIYAMA, S., ISCHIYAMA, K HASHIMITO, K. 2006. Anabolic effects of bee pollen Cistus ladaniferus extract on bone components in the femoral-diaphyseal and-metaphyseal tissues of rats in vitro and in vivo. Journal of Health Science, 52(1), 43-49. https://doi.org/10.1248/jhs.52.43

ZHOU, X., WANG, Y., GU, Q., LI, W. 2010. Effect of dietary probiotic, Bacillus coagulans, on growth performance, chemical composition, and meat quality of Guangxi Yellow chicken. Poultry Science, 89(3), 588-593. https://doi.org/10.3382/ps.2009-00319 